\title{
Zmiana granic pomiędzy gminami: ocena rządowej polityki zmian w podziale terytorialnym pozostaje poza granicami oceny dokonywanej przez Trybunał Konstytucyjny
}

Postanowienie Trybunału Konstytucyjnego z dnia 12 czerwca 2019 r., U 1/191

1. W świetle orzecznictwa Trybunału Konstytucyjnego, jak i w doktrynie (literaturze przedmiotu) brak jest zgodności odnośnie do tego, jaki jest w istocie charakter normatywny rozporządzenia w sprawie zmiany granic jednostek samorządu terytorialnego, a w zasadzie zgodności co do tego, czy jest to rozporządzenie o charakterze czysto normatywnym, czy też ma charakter hybrydowy, tzn. jest jednocześnie indywidualnym.

2. W niektórych sytuacjach rozporządzenie w sprawie ustalenia granic jednostek samorządu terytorialnego może nosić znamiona konkretności.

3. W tle uzasadnienia postanowienia Trybunału Konstytucyjnego można dostrzec poważny spór aksjologiczny o prawa jednostek samorządu terytorialnego w kontekście ich roli jako jednostek zasadniczego podziału terytorialnego państwa oraz spór ideologiczny o miejsce i charakter wspólnoty samorządowej w państwie unitarnym.

\section{Marek Mączyński}

Uniwersytet Jagielloński

marek.maczynski@uj.edu.pl

ORCID 0000-0001-8558-3361

https://doi.org/10.26881/gsp.2020.1.11

\section{Glosa}

W glosowanym postanowieniu Trybunał Konstytucyjny (dalej: TK lub Trybunał) odniósł się do wniosku Rady Gminy Stare Miasto o zbadanie konstytucyjności § 2 rozporządzenia Rady Ministrów z dnia 24 lipca 2017 r. w sprawie ustalenia granic niektórych gmin i miast, nadania niektórym miejscowościom statusu miasta, zmiany nazwy gmi-

1 OTK-A 2019, nr 32. 
ny oraz siedzib władz niektórych gmin (Dz. U. poz. 1427, ze zm.), w zakresie zmiany granicy pomiędzy gminą Stare Miasto i miastem na prawach powiatu Konin - polegającej na włączeniu do dotychczasowego obszaru Konina części obszaru gminy Stare Miasto.

Wnioskodawca kwestionował zgodność przedmiotowego rozporządzenia Rady Ministrów z:

1. art. 4 ust. 2 oraz art. 4b ust. 3 ustawy z dnia 8 marca 1990 r. o samorządzie gminnym (ówcześnie: Dz. U. z 2017 r., poz. 1875, ze zm., obecnie: Dz. U. z 2018 r., poz. 994, ze zm.) (dalej: u.s.g.) w związku z art. 92 ust. 1 zdanie pierwsze w zw. z art. 2 Konstytucji Rzeczypospolitej Polskiej z dnia 2 kwietnia 1997 r. (Dz. U. Nr 78, poz. 483, ze zm.) (dalej: Konstytucja RP) oraz w zw. z art. 7 Konstytucji RP - „poprzez naruszenie procedury wydania rozporządzenia w sprawie ustalenia granic gmin polegającego na tym, że postępowanie inicjujące jego wydanie zostało wszczęte na podstawie wniosku złożonego przez podmiot nieuprawniony";

2. art. 4b ust. 1 pkt 1 u.s.g. w zw. z art. 92 ust. 1 zdanie pierwsze w zw. z art. 2 Konstytucji RP oraz w zw. z art. 7 Konstytucji RP - „poprzez naruszenie procedury wydania rozporządzenia w sprawie ustalenia granic gmin polegającego na jego wydaniu w oparciu o niepełny wniosek zainteresowanej rady gminy";

3. art. 4 ust. 3 u.s.g. w zw. $z$ art. 92 ust. 1 zdanie pierwsze w zw. $z$ art. 2 i art. 7 Konstytucji RP oraz w zw. z art. 15 ust. 2 w zw. z art. 165 ust. 2 Konstytucji RP - „polegającego na ustaleniu granic gmin pomimo braku wystąpienia w sprawie lokalnego interesu publicznego (odmiennego od interesu własnego jednej z gmin objętych zmianą granic), który uzasadniałby naruszenie zasady stabilności granic gmin";

4. art. 4 ust. 3 u.s.g. w zw. $z$ art. 92 ust. 1 zdanie pierwsze w zw. z art. 2 i art. 7 Konstytucji RP oraz w zw. z art. 15 ust. 2 Konstytucji RP - „poprzez niezrealizowanie ustawowo określonych wytycznych wydania rozporządzenia w sprawie ustalenia granic gmin, do których należy zapewnienie gminom, których granice ulegają zmianie, terytorium możliwie jednorodnego pod względem przestrzennym";

5. art. 4 ust. 3 u.s.g. w zw. z art. 92 ust. 1 zdanie pierwsze Konstytucji RP w zw. z art. 2 Konstytucji RP oraz w zw. z art. 15 ust. 2 w zw. z art. 167 ust. 1 Konstytucji RP - „poprzez niezrealizowanie wytycznych ustawowych wydania rozporządzenia w sprawie ustalenia granic gmin, do których należy zapewnienie zdolności wykonywania zadań publicznych obu gminom po dokonanej zmianie";

6. art. 165 ust. 2 w zw. z art. 15 ust. 2 Konstytucji RP - „poprzez naruszenie zasady samodzielności gminy polegające na dokonaniu zmiany przebiegu granicy pomiędzy gminami w sytuacji braku spełnienia przesłanek celowości, niezbędności i proporcjonalności takiego naruszenia".

W glosowanym postanowieniu TK nie podzielił zarzutów gminy Stare Miasto i umorzył postępowanie. W uzasadnieniu postanowienia Trybunał podniósł przy tym, iż „z przedstawionego przez wnioskodawcę uzasadnienia zarzutów w sprawie wynikało, że zarzuty te dotyczyły nowej oceny faktów, nie odnosiły się natomiast do sfery normatywnej. Z tego względu to, czy w toku wydania zakwestionowanego przepisu rozporządzenia pominięto konkretne interesy lokalne, czy rozstrzygnięcie - oparte na prawie - było właściwe, czy skutki negatywne przeważają nad pozytywnymi, czy też 
odwrotnie, pozostaje poza granicami oceny dokonywanej przez TK". Tym samym Trybunał stwierdził, że nie jest powołany do oceny merytorycznej trafności i celowości przyjętych rozwiązań czy też do oceny zasadności polityki rządu w dziedzinie zmian w podziale terytorialnym, jak też do rozstrzygania konkretnych sporów dotyczących celowości zmian, popierając to argumentem, że czym innym jest kontrola celowości zamierzenia, a czym innym kontrola jego zgodności z konstytucją.

Stanowisko takie wpisuje się w linię orzeczniczą ugruntowaną wyrokiem TK wydanym w pełnym składzie w dniu 8 kwietnia 2009 r. (K 37/06, OTK ZU 2009, nr 4A, poz. 47), w którym mowa jest o odejściu od tezy o dopuszczalności badania rozporządzeń w sprawie ustalenia lub zmiany granic jednostek samorządu terytorialnego. W orzeczeniu tym TK wyjaśnił, że: „Rozporządzenia dokonujące zmian granic jednostek samorządu terytorialnego (...) mają szczególny charakter. W odniesieniu do tych rozporządzeń ocena konstytucyjności łączy się w większym stopniu z oceną faktów aniżeli z oceną obowiązujących norm (zob. wyrok z 25 marca 2003 r., sygn. U 10/01, OTK ZU nr 3/A/2003, poz. 23). Niezbędne jest zatem zachowanie w tej mierze koniecznej powściągliwości sędziowskiej. Mamy w tym przypadku do czynienia z rozporządzeniami określanymi w doktrynie jako »rozporządzenia« różniące się od rozporządzeń »klasycznych«, przewidzianych w art. 87 i art. 92 Konstytucji. Owe »rozporządzenia«, stanowiące przedmiot orzekania, różnią się od rozporządzeń »klasycznych« tym, że sensem ich wydania nie jest ustanowienie norm generalnych i abstrakcyjnych; nie mają więc one charakteru prawotwórczego, nie kreują norm prawnych i nie są podstawą ich obowiązywania, a przez ich wydanie dokonuje się czynności konwencjonalnej (...)".

Pogląd ten został podtrzymany w postanowieniach TK z dnia: 5 listopada 2009 r. (U 9/07, OTK ZU 2009, nr 10A, poz. 152) i 8 lutego 2017 r. (U 2/16, OTK ZU 2017, nr 4A, poz. 4).

Problem zgodności z Konstytucją art. 4, 4a i 4b oraz wydanych na ich podstawie przepisów wykonawczych był jednak wcześniej kilkakrotnie przedmiotem rozstrzygnięć TK. Szczegółowego przeglądu dotychczasowego orzecznictwa w odniesieniu do kontroli rozporządzeń w sprawie ustalenia lub zmiany granic jednostek samorządu terytorialnego (dalej: JST) Trybunał dokonał w przywołanym powyżej postanowieniu z dnia 8 lutego 2017 r. (U 2/16), w którym wskazał, że jednak w pierwszych sprawach dotyczących tych zagadnień, co do zasady, uznawał swoją kognicję do badania rozporządzeń w sprawie ustalenia lub zmiany granic JST.

Co więcej, już nawet pobieżny przegląd wcześniejszego orzecznictwa TK w sprawach ustalania lub zmiany granic JST pozwala zauważyć, że zwłaszcza kwestia charakteru rozporządzenia Rady Ministrów stanowi kolejny problem prawny i teoretyczny oraz mający niebagatelne znaczenie praktyczne. Otóż zarówno w świetle orzecznictwa Trybunału, jak i w doktrynie (literaturze przedmiotu) brak jest zgodności odnośnie do tego, jaki jest w istocie charakter normatywny rozporządzenia w sprawie zmiany granic JST, a w zasadzie zgodności co do tego, czy jest to rozporządzenie o charakterze czysto normatywnym, czy też ma charakter hybrydowy, tzn. jest jednocześnie indy- 
widualnym². Wszelka wątpliwość w tej materii może skutkować także niepewnością i dyskusyjnością jednej z absolutnie fundamentalnych, podstawowych cech konstytucyjnych samorządu terytorialnego, jaką jest jego charakter jako wspólnoty terytorialnej. Co prawda, jak to już wcześniej podnosiłem: „Trybunał konsekwentnie prezentuje stanowisko, że stabilne istnienie konkretnych jednostek samorządu terytorialnego w konkretnych granicach nie jest wartością przeważającą nad jakimikolwiek innymi względami, w szczególności nad racjami interesu publicznego o charakterze ogólnokrajowym. Dlatego TK uznał za zgodny z Konstytucją zabieg legislacyjny polegający na połączeniu gmin warszawskich w jedną gminę na mocy ustawy z dnia 15 marca 2002 r. o ustroju miasta stołecznego Warszawy (Dz. U. Nr 41, poz. 361, ze zm.)"3.

Na przykład w wyroku z dnia 4 listopada 2003 r. (K 1/03) Trybunał, oceniając rozporządzenie w sprawie ustalenia granic jednostek samorządu terytorialnego, w uzasadnieniu orzeczenia zaznaczył, że akt ten nosi znamiona konkretności. Stwierdził, że: „rozporządzenia, o których mowa w art. 4 ustawy [o samorządzie gminnym] są w istocie rozstrzygnięciami, a więc mają pewne znamiona konkretności. Materia rozstrzygnięć powoduje, iż wytyczne treściowe do wydawania rozporządzeń mają charakter raczej kierunkowy, tzn. »naprowadzający« niejako na ochronę pewnych dóbr przy podejmowaniu decyzji o zmianie granic". Z kolei w wyroku z dnia 18 lipca 2006 r. (U 5/04) TK podkreślił, że: „materia zmiany granic gmin (...) dotyczy rozstrzygania spraw o charakterze jednostkowym, konkretnym, jednakże przybierających postać aktu normatywnego - rozporządzenia Rady Ministrów. Choć rozstrzygnięcie to odnosi się do zmiany granic imiennie określonej gminy lub gmin, to koryguje ono odpowiednio także podział terytorialny kraju oraz wpływa kształtująco na zdolność wykonywania zadań publicznych przez te gminy, a także na prawa polityczne i interesy ich mieszkańców". Podobne stanowisko TK zajął w wyroku z dnia 5 grudnia 2006 r. (U 2/06).

Z kolei w wyroku z dnia 27 listopada 2000 r. (U 3/00, OTK ZU 2000, nr 8, poz. 293) Trybunał odniósł się do kwestii spełniania przez rozporządzenia Rady Ministrów w sprawach zmiany granic JST przyjmowanych w orzecznictwie TK kryteriów generalności i abstrakcyjności. W wyroku tym podkreślono m.in., że „nie ulega wątpliwości, iż właściwość orzecznicza Trybunału wiąże się z kontrolą konstytucyjności, bądź także legalności aktów stanowienia prawa. Pojęcie "przepisy prawa«, jakim operuje ustrojodawca w art. 188 pkt 3 Konstytucji, obejmuje swoim zakresem wszystkie akty stanowione przez centralne organy państwowe, które zakwalifikować można jako źródła prawa, a więc ustanawiające dla określonych kategorii adresatów wzorce pewnych zachowań (nakazanych, zakazanych). W tym znaczeniu zwrot »przepisy prawa« koresponduje z terminem »źródła prawa«, zastosowanym w tytule rozdziału III Konstytucji. Nie ulega wątpliwości, że zamieszczenie zakwestionowanych przez rady gmin przepisów w rozporządzeniu Rady Ministrów nie może być uznane za okoliczność nie mającą

\footnotetext{
2 Por. Z. Cieślak, Samorządy przed Trybunałem Konstytucyjnym, http://niezniknelo.pl/OK2/trybunal/ samorzady-przed-trybunalem-konstytucyjnym/6/index.html [dostęp: 15.11.2019].

3 M. Mączyński, Komentarz do art. 4-4f u.s.g., t. 12 [w:] Ustawa o samorzqdzie gminnym. Komentarz, red. P. Chmielnicki, Warszawa 2013, s. 124.
} 
żadnego znaczenia dla oceny ich treści, właśnie z punktu widzenia »normatywności«. Nie jest to oczywiście okoliczność przesądzająca, wszak w orzecznictwie Trybunału Konstytucyjnego wielokrotnie podkreślano, że dla oceny charakteru danego aktu decydujące znaczenie winna mieć analiza jego treści, nie zaś wyłącznie forma prawna. Tym niemniej uznać można, że przyjęciu w przepisie upoważniającym w ustawie o samorządzie gminnym (art. 4 ust. 1) formy rozporządzenia Rady Ministrów dla unormowania materii dotyczących tworzenia, łączenia, podziału i znoszenia gmin, ustalania ich granic i nazw oraz siedzib władz, towarzyszyła pełna świadomość ustawodawcy wyboru formy prawnej »typowej« dla wyrażania unormowań o charakterze generalnym i abstrakcyjnym. Trzeba w tym zakresie odwołać się również do konsekwencji, jakie dla oceny charakteru prawnego rozporządzenia miało uwzględnienie tej formy aktu prawnego w wyliczeniu źródeł prawa powszechnie obowiązującego, zawartym w art. 87 ust. 1 Konstytucji. Jedną z tych konsekwencji jest konieczność traktowania rozporządzenia w sposób jednolity, jako formy aktu prawotwórczego, ustanawiającego wzorce zachowań dla określonych (nie ograniczonych jedynie do jednostek podległych organizacyjnie temu, kto rozporządzenie wydaje) kategorii adresatów. Dobór takiej formy prawnej przez ustawodawcę może być więc potraktowany jako swoiste domniemanie takiego właśnie charakteru zawartych w rozporządzeniu postanowień. W świetle dominującego w orzecznictwie Trybunału Konstytucyjnego »materialnego« podejścia do problemu definiowania aktów normatywnych, przesądzającego znaczenia nabiera jednak analiza treści zakwestionowanych we wnioskach rad gmin postanowień rozporządzenia Rady Ministrów. Nie ulega wątpliwości, że sposób sformułowania treści zaskarżonych przepisów rozporządzenia utrudnia jednoznaczne wyodrębnienie takich ich części, które odpowiadałyby tradycyjnym elementom normy prawnej, tzn. hipotezy (określenie adresata i okoliczności zastosowania) oraz dyspozycji (określenie wzoru powinnego zachowania). W ocenie Trybunału Konstytucyjnego w odniesieniu do cechy generalności w pełni uzasadnione jest przyjęcie, że adresatem regulacji (...) rozporządzenia Rady Ministrów nie jest indywidualnie wskazany podmiot, ale ich różne kategorie. Trzeba bowiem podkreślić, iż adresatem zakwestionowanych przepisów nie mogą być jedynie organy państwa powołane do technicznego wprowadzenia w życie uregulowania przewidującego przypisanie określonych obszarów do konkretnych gmin. Za adresatów przepisów (...) rozporządzenia Rady Ministrów winny być uznane wszystkie podmioty prawa (a więc zarówno mieszkańcy przedmiotowych wsi, jak i wszelkie organy i instytucje publiczne), które w zakresie swoich działań (faktycznych czy prawnych, prywatnych bądź urzędowych) zetkną się z problemem przynależności danej wsi do określonej gminy. Trzeba podkreślić, iż niejednoznaczny sposób określenia adresata normy prawnej nie może być przesądzający o odmowie przyznania jej generalnego charakteru. Wskazać w tym miejscu można pogląd J. Wróblewskiego, dla którego nawet wyraźne zastosowanie przez prawodawcę nazwy jednostkowej nie przesądza jeszcze indywidualnego charakteru normy, której adresat jest w ten właśnie sposób opisany (por. J. Wróblewski, Norma generalna i norma indywidualna, "Zeszyty Naukowe Uniwersytetu Łódzkiego”, Seria I, Prawo, z. 23, s. 6). Autor ten wskazuje również na zachodzącą w pewnych przypadkach 
konieczność dekodowania adresata danej normy z opisu przedmiotu jej unormowania, a więc właśnie z zakresu zachowań, których będzie ona dotyczyć, a z taką sytuacją mamy do czynienia w niniejszej sprawie. W odniesieniu do problemu oceny abstrakcyjnego charakteru regulacji zakwestionowanych przez rady gmin, zdaniem Trybunału Konstytucyjnego także i pod względem sposobu opisania powinnego zachowania zaskarżone przepisy rozporządzenia Rady Ministrów spełniają »materialne« kryterium normatywności. Normatywnej treści zakwestionowanych przepisów nie sposób bowiem ograniczać wyłącznie do samego, jedynie »technicznego « wyznaczenia nowych granic gmin. Normy wyrażone w $\S 5$ pkt 2 i $§ 11$ rozporządzenia Rady Ministrów nie »spełniają się« wyłącznie jednorazowym ich wykonaniem. Zawarte w nich unormowania stanowić będą w przyszłości część składową podstawy normatywnej (treściowej, proceduralnej, kompetencyjnej) dla podejmowania konkretnych rozstrzygnięć o charakterze indywidualnym i konkretnym. Kierując się formułowanym w orzecznictwie Trybunału Konstytucyjnego wskazaniem, iż o abstrakcyjności danej normy świadczy to, iż nie »konsumuje« się ona wskutek jednorazowego jej wykonania, należy uznać, że w przypadku zaskarżonych przepisów rozporządzenia Rady Ministrów do takiego skutku nie dochodzi. Istotnie, przepisy te nie będą już rodziły powinności ponownej ich »technicznej« realizacji, ale jednak nie utracą one swojej normatywnej aktualności, determinując treść rozstrzygnięć podejmowanych w przyszłości także na ich podstawie. Przesądzać będą przede wszystkim o właściwości organów dokonujących aktów stosowania prawa w konkretnych sprawach należących do zakresu zadań »nowych « gmin. W ocenie Trybunału Konstytucyjnego należy więc przyjąć, że zakwestionowane normy rodzą w określonych okolicznościach nakaz określonego typu postępowania, wprawdzie nie samoistnie i samodzielnie w oderwaniu od innych unormowań, ale współkształtując treść przyszłych aktów stosowania prawa".

Rozporządzenia Rady Ministrów w sprawie ustalenia lub zmiany granic JST były również przedmiotem merytorycznej oceny TK $w$ wyrokach z dnia: 25 marca $2003 \mathrm{r}$. (U 10/01, OTK ZU 2003, nr 3A, poz. 23); 4 listopada 2003 r. (K 1/03, OTK ZU 2003, nr 8A, poz. 85); 1 czerwca 2004 r. (U 2/03, OTK ZU 2004, nr 6A, poz. 54); 18 lipca 2006 r. (U 5/04, OTK ZU 2006, nr 7A, poz. 80); 5 grudnia 2006 r. (U 2/06, OTK ZU 2006, nr 11A, poz. 168).

Tym niemniej $w$ glosowanym postanowieniu TK podzielił stanowisko zajęte $w$ wyroku o sygnaturze akt K 37/06 wydanym w pełnym składzie i przyjął, że rozporządzenie $w$ sprawie ustalenia lub zmiany granic jednostki samorządu terytorialnego nie ma charakteru normatywnego i nie należy do kategorii określonej w art. 188 pkt 3 Konstytucji RP. To, że akt ten pośrednio oddziałuje na sytuację prawną podmiotów prawa, nie znaczy, że można z niego wywieść reguły postępowania o charakterze generalnym i abstrakcyjnym. Mimo że z punktu widzenia formalnego akt, jakim jest rozporządzenie, jest wymieniony w art. 87 ust. 1 Konstytucji RP w katalogu źródeł prawa powszechnie obowiązującego, to okoliczność ta nie zwalnia Trybunału z oceny, czy w treści takiego aktu występują normy o charakterze generalnym i abstrakcyjnym. W szczególności ma to znaczenie w kontekście treści art. 188 pkt 3 Konstytucji RP, który stanowi, że Trybunał orzeka w sprawach zgodności przepisów prawa, wydawanych przez central- 
ne organy państwowe, z Konstytucją, ratyfikowanymi umowami międzynarodowymi i ustawami (zob. postanowienie TK z dnia 8 lutego 2017 r., U 2/16).

Dlatego też TK przyjął, że skoro w art. 188 Konstytucji RP określającym kognicję Trybunału do orzekania w sprawach zgodności określonych aktów z aktami wyższego rzędu nie wymieniono expressis verbis rozporządzeń, to dopuszczalność kontroli rozporządzenia będzie możliwa jedynie po spełnieniu przez ten akt kryterium materialnego, czyli wtedy, gdy będzie zawierał on „przepisy prawa” w rozumieniu art. 188 pkt 3 Konstytucji RP. Zdaniem TK dla oceny charakteru prawnego danego aktu decydujące znaczenie powinna mieć analiza jego treści, a nie wyłącznie jego forma prawna.

Trybunał, mając więc na uwadze treść uzasadnienia postanowienia w sprawie o sygnaturze akt U 2/16, przyjął, że skoro aktualna jest teza TK, iż rozporządzenie nie musi mieć charakteru normatywnego w każdym przypadku i nie zawsze należy do kategorii określonej w art. 188 pkt 3 Konstytucji RP, to w niniejszej sprawie zbadanie przez Trybunał Konstytucyjny zgodności przepisu § 2 rozporządzenia Rady Ministrów w zakresie podnoszonych przez wnioskodawcę zarzutów zarówno o charakterze proceduralnym, jak i materialnym - ze wskazanymi w petitum wniosku wzorcami konstytucyjnymi oraz ustawowymi nie jest dopuszczalne, co jednocześnie oznacza konieczność umorzenia postępowania w niniejszej sprawie na podstawie art. 59 ust. 1 pkt 2 ustawy o organizacji i trybie postępowania przed Trybunałem Konstytucyjnym ${ }^{4}$, gdyż zarzuty wnioskodawcy ogniskują się wokół problemu zasadności konkretnego przesunięcia terytorialnego między dwiema gminami.

Nie oznacza to jednak, że z całą argumentacją TK należy się w tym zakresie w całości bezwzględnie zgadzać. Zasadza się ona bowiem na pryncypialnym uznaniu za zgodne z Konstytucją RP przepisy upoważniające Radę Ministrów do dokonywania zmiany granic gmin. Problemem może być już to, iż upoważnienie Rady Ministrów do zmiany granic gminy powoduje, że Rada Ministrów określa zarazem jedną z najważniejszych konstytutywnych cech wspólnoty, jaką jest jej liczebność oraz związane z tym możliwości działania, a tym samym niewątpliwe może to godzić w samodzielność JST. Stanowisko doktryny nie jest bynajmniej w tej materii wcale takie jednoznaczne. Owszem, nie neguje się, że kompetencja Rady Ministrów do tworzenia, dzielenia i znoszenia gmin wynika z faktu, iż gmina jest podstawową jednostką zasadniczego podziału terytorialnego państwa. Na Radzie Ministrów, jako strażniku interesu publicznego, ciąży w tym przypadku obowiązek racjonalnego ukształtowania podziału terytorialnego. Dotyczy to także ustalania granic, nazw i siedzib władz (organów) gminy, jak też nadawania gminie statusu miasta i ustalania jego granic. Zdaniem A. Szewca, „wbrew pozorom nie są to sprawy lokalne, lecz sprawy ogólnokrajowe, związane z podziałem terytorialnym państwa, ergo nie należące do zakresu działania gminy ustalonego w art. 6 u.s.g." ${ }^{\prime 5}$ Konsekwencją takiego stanu rzeczy jest m.in. fakt, że w przypadku inicjowania tego rodzaju zmian na wniosek zainteresowanej rady gminy, co przewiduje

4 Ustawa z dnia 30 listopada 2016 r. o organizacji i trybie postępowania przed Trybunałem Konstytucyjnym (tekst jedn.: Dz. U. z 2019 r., poz. 2393).

5 A. Szewc, G. Jyż, Z. Pławecki, Ustawa o samorządzie gminnym. Komentarz, Warszawa 2000, s. 44. 
ust. 2 komentowanego przepisu, zgodnie z art. 4b ust. 1 pkt 3 wymagana jest także opinia wojewody właściwego dla gminy lub gmin objętych wnioskiem. Odmienny pogląd w tym względzie wyraża Z. Niewiadomski, który twierdzi, że regulacja art. 4 ust. 1 jest istotnym odstępstwem od ustawowej formy tworzenia samorządu i podkreśla, iż „ustalanie nazw gmin i siedzib ich władz można z powodzeniem zostawić samej gminie" $^{\prime \prime}$. Jeszcze dalej w tym względzie posunęli się P. Czechowski i S. Piątek, którzy wskazali, iż ustawodawca, przyznając Radzie Ministrów uprawnienie do tworzenia, łączenia, podziału i znoszenia gmin, w istotny sposób wkroczył w konstytucyjną oraz ustawowo zagwarantowaną samorządność gmin ${ }^{7}$.

Ponadto rozporządzenia wydawane przez Radę Ministrów w sprawach wymienionych w art. 4 ust. 1 pkt 1-3 u.s.g. należy uznać za szczególnego rodzaju akty wykonawcze do ustawy o samorządzie gminnym, które jako takie podlegają ocenie w aspekcie zgodności ich treści z zakresem delegacji ustawowej. Celem rozporządzenia wydawanego przez Radę Ministrów jest „wykonanie ustawy”, co wynika m.in. z komplementarności rozporządzenia względem ustawy. Nie może ono zawierać treści „konkurencyjnej i autonomicznej" względem ustawy ${ }^{8}$. Zgodnie z zastrzeżeniem konstytucyjnym (art. 92 ust. 1 Konstytucji RP) organ upoważniony do wydania rozporządzenia nie może przekazać swoich kompetencji innemu organowi, co również dowodzi ściśle wykonawczej koncepcji samego rozporządzenia. Z przepisów ustawy zasadniczej wynika zatem zakaz tworzenia tzw. upoważnień kaskadowych. Tak więc uprawnienie do nałożenia na określony podmiot prawny danego obowiązku musi wynikać albo wprost z ustawy, albo z przepisu rozporządzenia wydanego tylko na podstawie i w granicach ustawowego (wyraźnego) upoważnienia (wyrok NSA z dnia 10 września 2001 r., II SA 1973/00, LexPolonica nr 2148046). Ponadto Sąd Najwyższy (wyrok z dnia 6 stycznia 1999 r., III RN 108/98, OSNAPiUS 1999, nr 20, poz. 639) wskazał, że niewykonanie przez Radę Ministrów obowiązku wynikającego z kompetencji do wydania rozporządzenia zapewniającego prawidłowe wykonanie ustawy (art. 146 ust. 4 pkt 1 i 2 w zw. z art. 92 Konstytucji RP) narusza konstytucyjne zasady funkcjonowania demokratycznego państwa prawnego (art. 2 i 7 Konstytucji RP), a tym samym może stanowić delikt konstytucyjny.

Potwierdzeniem takiego stanu rzeczy jest np. stanowisko wyrażone przez TK w wyroku z dnia 1 czerwca 2017 r. (U 3/17, Dz. U. poz. 1134), w którym Trybunał orzekł, że rozporządzenie Rady Ministrów z dnia 28 grudnia 2015 r. uchylające rozporządzenie w sprawie utworzenia gminy Szczawa i gminy Grabówka (Dz. U. poz. 2312) jest niezgodne z art. 7 i art. 92 ust. 1 Konstytucji RP i art. 4a ust. 1 u.s.g. Warto przy tym zauważyć, że zgodnie z art. 4a i 4b u.s.g. wszelkie decyzje i czynności Rady Ministrów w sprawach podziału, łączenia, dzielenia i znoszenia gmin, jak też w sprawie ustalania ich granic i siedzib władz powinny być podejmowane dopiero po przeprowadzeniu

\footnotetext{
6 Z. Niewiadomski, Ustawa o samorzq̨dzie terytorialnym z komentarzem, Warszawa 1990, s. 8.

7 Prawo samorządu terytorialnego. Przepisy z komentarzem, red. P. Czechowski, S. Piątek, Warszawa 1997, s. 14.

8 Rada Ministrów. Organizacja i funkcjonowanie, red. A. Bałaban, Kraków 2000, s. 263.
} 
konsultacji z mieszkańcami. Ustawa jednak nie określa ich formy, stanowiąc jedynie, że zasady i tryb konsultacji powinny zostać określone uchwałą rady gminy (art. 5a ust. 2 u.s.g.). Tym samym konsultacje mogą mieć formę dowolną, w tym nawet referendalną. W tej ostatniej kwestii w doktrynie dało się zauważyć liczne kontrowersje odnośnie do charakteru prawnego takich konsultacji, głównie w związku z tym, że referendum ma co do zasady charakter rozstrzygający, natomiast stanowisko mieszkańców wyrażone w konsultacji ma mieć charakter jedynie opiniodawczy, a więc niewiążący Rady Ministrów przy podejmowaniu decyzji (por. stanowisko Naczelnego Sądu Administracyjnego, że przedmiotem referendum gminnego nie może być opiniodawcze stanowisko rady gminy lub innego organu wypowiedziane w sprawie nienależącej do zakresu działania gminy wyrażone w postanowieniu NSA z dnia 29 czerwca 1993 r., SA/Wr 935/93, ONSA 1994, nr 3, poz. 105). Odmienne stanowisko zajął NSA w wyroku z dnia 28 lutego 2001 r. (II SA/Ld 297/01, niepubl.), w którym wyraził pogląd, że dopuszczalne jest przeprowadzenie referendum w sprawie podjęcia przez radę gminy uchwały o wystąpieniu do Rady Ministrów z wnioskiem o dokonanie podziału gminy. W takim przypadku wynik referendum nie rozstrzygałby oczywiście o podziale gminy, ale byłby wiążący w tym sensie, że obligowałby radę gminy do wystąpienia z wnioskiem w tej sprawie do Rady Ministrów. Ostatecznie kwestię tę rozstrzygnął TK, który w swoim wyroku z dnia 26 lutego 2003 r. (K 30/02, Dz. U. Nr 44, poz. 388) uznał za słuszną interpretację przepisów konstytucyjnych, w szczególności art. 170 Konstytucji RP, prowadzącą do wniosku, że wszędzie tam, gdzie w grę wchodzi tworzenie, łączenie, podział lub znoszenie jednostek samorządu terytorialnego, a zwłaszcza gmin, a także zmiana ich granic przez centralne organy władz publicznych, które poprzedzone powinno być opinią organów stanowiących jednostek dotkniętych zmianami i konsultacjami z mieszkańcami - mieszkańcy mają prawo do wyrażenia swojego stanowiska w drodze referendum konsultacyjnego. Zdaniem TK: „Wynik takiego referendum wiąże, jeśli chodzi o opinię organów stanowiących odpowiednich jednostek samorządowych". Przywołany wyrok Trybunału Konstytucyjnego stanowił podstawę dla nowelizacji ustawy o samorządzie gminnym, w ramach której dodany został m.in. art. 4c (dodany ustawą z dnia 26 maja 2011 r. o zmianie ustawy o samorządzie gminnym oraz niektórych innych ustaw, Dz. U. Nr 134, poz. 777) stanowiący, że w sprawie utworzenia, połączenia, podziału i zniesienia gminy oraz ustalenia granic gminy może być przeprowadzone referendum lokalne z inicjatywy mieszkańców. W przypadku przeprowadzenia referendum lokalnego w sprawie utworzenia, połączenia, podziału i zniesienia gminy oraz ustalenia granic gminy, o którym mowa w art. 4c u.s.g., konsultacji z mieszkańcami, o których mowa w art. 4 a ust. 1 i 2 u.s.g., nie przeprowadza się (art. 4a ust. 4 u.s.g.). Pozytywny wynik takiego referendum jest dla rady gminy wiążący, w tym sensie, że jest ona zobowiązana wystąpić do Rady Ministrów z wnioskiem o wydanie rozporządzenia, o którym mowa w art. 4 ust. 1 pkt 1 u.s.g., jednakże ostateczna decyzja w sprawie zmiany granic pozostaje nadal w wyłącznej kompetencji Rady Ministrów, natomiast sam wynik głosowania w referendum nie przesądza o dokonaniu zmian, a jedynie - podobnie jak uchwały gmin podejmowane $w$ trybie art. 4b w sprawie zmian granic jednostki podstawowego podziału terytorialnego - stanowi postulat pod adresem Rady Ministrów odnośnie 
do zmian w zakresie istniejącego podziału terytorialnego i nie przesądza o wydaniu rozporządzenia przez Radę Ministrów w tej sprawie, gdyż zgodnie z art. 4 ust. 2 u.s.g. może, a nie musi, być ono wydane na wniosek gminy.

Ważna jest także konstatacja, że Trybunał Konstytucyjny, wydając wyrok z dnia 1 czerwca 2017 r. (U 3/17), zwrócił uwagę na konieczność dochowania staranności w przestrzeganiu procedur konsultacyjnych w procesie tworzenia prawa, w szczególności jeśli chodzi o sprawy dotyczące obywateli, a szerzej mieszkańców poszczególnych szczebli jednostek samorządu terytorialnego i podkreślił, że: „Możliwość wyrażenia opinii w sprawach lokalnych czy regionalnych o kształcie granic danej jednostki samorządowej przez jej mieszkańców jest jednym z podstawowych elementów zasady demokratycznego państwa prawnego. Mimo że ostateczną decyzję w sprawie kształtu tych jednostek podejmuje Rada Ministrów, która zgodnie z art. 146 ust. 1 Konstytucji prowadzi politykę wewnętrzną i zagraniczną Rzeczypospolitej Polskiej, mieszkańcy jednostek samorządu terytorialnego muszą mieć możliwość zajęcia stanowiska w sprawach ich dotyczących. Pominięcie prawa do wyrażenia takiej opinii narusza podstawy demokracji".

Konkludując, można powiedzieć, że jak wynika z powyższych uwag i rozważań, glosowane uzasadnienie postanowienia TK w takiej samej mierze zasługuje na aprobatę, jak skłania do dalszych deliberacji i przemyśleń. W obecnym stanie prawnym dyskusyjne mogą być pewne elementy uzasadnienia, nawet jeśli co do istoty uznamy je za słuszne. Trybunał uznał, że proponowane zmiany nie są sprzeczne z Konstytucją RP. Mając jednak na uwadze dotychczas poczynione uwagi, można by też uznać, że przepis § 2 rozporządzenia w objętym wnioskiem zakresie, choć zawiera władcze rozstrzygnięcie co do przebiegu granicy między gminą Miasto Stare a miastem na prawach powiatu Konin, to jednak równocześnie kształtuje w sposób generalny zakres zadań tych gmin oraz zdolność do realizacji tych zadań przez gminy, a także w pewnym stopniu wyznacza w sposób generalny i abstrakcyjny prawa i obowiązki mieszkańców tych gmin oraz innych podmiotów prawa - które w zakresie swoich działań (faktycznych czy prawnych, prywatnych bądź urzędowych) zetkną się z problemem przynależności danego obszaru do określonej gminy? .

Trybunał Konstytucyjny w uzasadnieniu postanowienia uznał także, że nie jest powołany do oceny merytorycznej trafności i celowości przyjętych rozwiązań, czy też do oceny zasadności polityki rządu w dziedzinie zmian w podziale terytorialnym, jak też do rozstrzygania konkretnych sporów dotyczących celowości zmian. Jednakże w tle owego uzasadnienia zawsze będzie można dostrzec poważny spór aksjologiczny o prawa jednostek samorządu terytorialnego w kontekście ich roli jako jednostek zasadniczego podziału terytorialnego państwa i - być może znacznie poważniejszy - spór ideologiczny o miejsce i charakter wspólnoty samorządowej w państwie unitarnym ${ }^{10}$. Wydaje się bowiem, że konstatacja M. Kuleszy, iż „,dzisiejszy ustawodawca polski

\footnotetext{
9 Por. B. Dolnicki, Indywidualny akt normatywny, PPP 2017, nr 6, s. 68.

${ }^{10}$ Por. L. Kieres, Unitarność a samodzielność samorzqdu terytorialnego w orzecznictwie Trybunału Konstytucyjnego [w:] Unitarny charakter państwa a samorząd terytorialny, red. M. Stec, K. Małysa-Sulińska,
} 
nadal grzeszy niewybaczalnym anachronizmem, nie zapewniając wystarczająco silnej ochrony podmiotowego statusu wspólnot samorządowych przed swobodną ingerencją władz centralnych"11, jest - bardziej de lege ferenda aniżeli w odniesieniu do samego postanowienia TK - wciąż aktualna.

\section{Literatura}

Bandarzewski K., Chmielnicki P., Kisiel W., Prawo samorzq̨du terytorialnego w Polsce, Warszawa 2006.

Cieślak Z., Samorzq̨dy przed Trybunałem Konstytucyjnym, http://niezniknelo.pl/OK2/trybunal/samorzady-przed-trybunalem-konstytucyjnym/6/index.html [dostęp: 15.11.2019].

Dolnicki B., Samorząd terytorialny, Warszawa 2012.

Dolnicki B., Indywidualny akt normatywny „, Przegląd Prawa Publicznego" 2017, nr 6.

Dolnicki B., Ustawa o samorządzie terytorialnym. Komentarz, Warszawa 2018.

Izdebski H., Domniemanie zadań samorzq̨du terytorialnego i domniemanie zadań gminy w obrębie samorządu terytorialnego - klauzule generalne dotyczące zadań samorządu, ,'Samorząd Terytorialny" 2015, nr 1-2.

Kieres L., Samorzq̨d terytorialny jako instytucja społeczeństwa obywatelskiego, „Ruch Prawniczy, Ekonomiczny i Socjologiczny" 2006, z. 2.

Kieres L., Unitarność a samodzielność samorzq̨du terytorialnego w orzecznictwie Trybunału Konstytucyjnego [w:] Unitarny charakter państwa a samorząd terytorialny, red. M. Stec, K. Małysa-Sulińska, Warszawa 2019.

Kisiel W., Konstytucyjna "wspólnota samorządowa": instytucja prawna czy nazwa pusta? [w:] Teoretyczne i prawne problemy stosowania Konstytucji RP, red. K. Działocha, Wrocław 2005.

Kulesza M., Niecentralizacja, decentralizacja, centralizacja, "Gazeta Samorządu i Administracji” 2005, nr 199.

Kulesza M., O tym, ile jest centralizacji w decentralizacji, a także o osobliwych nawykach uczonych administratywistów, ',Samorząd Terytorialny" 2009, nr 12.

Leoński Z., Samorząd terytorialny w RP, Warszawa 2006.

Mączyński M., Konstytucyjne pojęcie samorzq̨du terytorialnego a idea samorzq̨dności [w:] Konstytucyjne umocowanie samorządu terytorialnego, red. M. Stec, K. Małysa-Sulińska, Warszawa 2018.

Niewiadomski Z., Ustawa o samorządzie terytorialnym z komentarzem, Warszawa 1990.

Oniszczuk J., Samorząd terytorialny w orzecznictwie Trybunału Konstytucyjnego, Warszawa 2002.

Prawo samorządu terytorialnego. Przepisy z komentarzem, red. P. Czechowski, S. Piątek, Warszawa 1997.

Rada Ministrów. Organizacja i funkcjonowanie, red. A. Bałaban, Kraków 2000.

Stec M., Małysa-Sulińska K., Unitarny charakter państwa a samorzq̨d terytorialny, Warszawa 2019. Szewc A., Jyż G., Pławecki Z., Ustawa o samorządzie gminnym. Komentarz, Warszawa 2000. Ustawa o samorzq̨dzie gminnym, Komentarz, red. P. Chmielnicki, Warszawa 2013.

Warszawa 2019; M. Mączyński, Konstytucyjne pojęcie samorządu terytorialnego a idea samorządności [w:] Konstytucyjne umocowanie samorzq̨du terytorialnego, red. M. Stec, K. Małysa-Sulińska, Warszawa 2018.

11 Por. M. Kulesza, Niecentralizacja, decentralizacja, centralizacja, GSiA 2005, nr 199. 


\section{Streszczenie}

\section{Marek Mączyński}

Zmiana granic pomiędzy gminami: ocena rządowej polityki zmian w podziale terytorialnym pozostaje poza granicami oceny dokonywanej przez Trybunał Konstytucyjny

W glosowanym postanowieniu Trybunał Konstytucyjny odniósł się do wniosku Rady Gminy Stare Miasto o zbadanie konstytucyjności § 2 rozporządzenia Rady Ministrów z dnia 24 lipca 2017 r. w sprawie ustalenia granic niektórych gmin i miast, nadania niektórym miejscowościom statusu miasta, zmiany nazwy gminy oraz siedzib władz niektórych gmin (Dz. U. poz. 1427, ze zm.), w zakresie zmiany granicy pomiędzy gminą Stare Miasto i miastem na prawach powiatu Konin - polegającej na włączeniu do dotychczasowego obszaru Konina części obszaru gminy Stare Miasto. Trybunał umorzył postępowanie w tej sprawie i stwierdził, że nie został powołany do oceny merytorycznej dokładności i celowości przyjętych rozwiązań ani do oceny zasadności polityki rządu w zakresie zmian podziału terytorialnego, a także do rozstrzygania konkretnych sporów dotyczących celowości zmian, popierając to argumentem, że czymś innym jest kontrola celowości zamierzenia, a czymś innym kontrola jego zgodności z konstytucją.

Jednak w świetle orzecznictwa Trybunału Konstytucyjnego i doktryny nie ma zgody co do normatywnego charakteru regulacji dotyczącej zmiany samorządu terytorialnego ani pełnej zgodności co do tego, czy jest to regulacja czysto normatywna, czy też hybrydowa, tj. także indywidualna. W niektórych bowiem sytuacjach rozporządzenie w sprawie określania granic jednostek samorządu terytorialnego może charakteryzować się konkretnością (nosić znamiona konkretności).

Ponadto w tle uzasadnienia decyzji Trybunału Konstytucyjnego można dostrzec poważny spór aksjologiczny dotyczący praw jednostek samorządu terytorialnego w kontekście ich roli jako jednostek podstawowego podziału terytorialnego państwa oraz sporu ideologicznego o miejsce i charakter (naturę) wspólnoty samorządowej w państwie unitarnym.

Tak więc postanowienie o umorzeniu w takiej samej mierze może zasługiwać na aprobatę, jak i skłaniać do dalszych deliberacji i przemyśleń na tyle istotnych, że może to nawet stanowić asumpt do postawienia pytania, czy aby postanowienie nie jest dowodem na niewystarczającą ochronę podmiotowego statusu społeczności lokalnych przed swobodną ingerencją władz centralnych.

\section{Summary}

\section{Marek Mączyński}

Changing borders between municipalities: The assessment of the government's policy in regard to changes in territorial division remains outside the scope of assessment made by the Constitutional Tribunal

In the commented judgement, the Constitutional Tribunal referred to the application of the municipal council of Stare Miasto to examine the constitutionality of $\S 2$ of the Regulation of the Council of Ministers of 24 July 2017 on establishing the boundaries of certain municipalities 
and cities, granting certain cities the status of the city, changing the name of the municipality and the seat of the authorities of some municipalities (Journal of Laws "Dziennik Ustaw", item 1427 , with later amendments), in the scope of changing the border between the municipality of Stare Miasto and the city of Konin with poviat rights - involving the inclusion of the part of the municipality of Stare Miasto to the city of Konin. The Constitutional Tribunal discontinued the proceedings in this case and stated that it was not appointed to assess the substantive accuracy and purposefulness of the solutions adopted or to assess the legitimacy of the government's policy regarding changes in the territorial division, as well as to settle specific disputes regarding the desirability of changes, supporting this with the argument that something else is the control of the purposefulness of the intention, and another thing is the control of its compliance with the constitution.

However, in the light of the jurisprudence of the Constitutional Tribunal and doctrine, there is no consensus as to the normative nature of the regulation regarding the change of territorial self-government, or full agreement whether it is a purely normative regulation or a hybrid regulation, i.e. also individual. In some situations, the regulation on determining the boundaries of local government units may be characterized by specificity.

In addition, there is a serious axiological dispute regarding the rights of local government units in the context of their role as units of basic territorial division of the state, as well as an ideological dispute over the place and nature of the local government community in a unitary state, noticeable in the background of the justification of the Constitutional Tribunal's judgement.

Thus, the decision to discontinue the proceedings may deserve approval and encourage further deliberation and reflection so important that it can even be a reason to ask whether the decision is not evidence of insufficient protection of the subjective status of local communities against free interference by central authorities.

Słowa kluczowe: samorząd terytorialny, zmiana granic gminy (JST), Rada Ministrów, Trybunał Konstytucyjny

Keywords: local government, change of the municipality's boundaries, Constitutional Tribunal 